\title{
Marcin Żurawski
}

Uniwersytet Mikołaja Kopernika, Toruń

zurawski@doktorant.umk.pl

\section{Jednolity europejski dokument zamówienia - aspekty prawne}

DOI: http://dx.doi.org/10.12775/SIT.2017.042

\section{Wprowadzenie}

Unijny system prawa jednolitego europejskiego dokumentu zamówienia jest rozwiązaniem nowym ze względu na sposób regulacji i zastosowane instytucje prawa unijnego, a także pod kątem celów, jakim ma służyć, oraz charakteru prawnego samego dokumentu jako oświadczenia wykonawcy w postępowaniu o udzielenie zamówienia publicznego. Zastosowane rozwiązania mają wpływ na realizację celów zamówień publicznych w Unii Europejskiej. Wprowadzenie nowych rozwiązań powoduje zróżnicowane konsekwencje natury prawnej, rodzi też pewne zastrzeżenia co do możliwości jego stosowania w praktyce.

Na mocy Dyrektywy Parlamentu Europejskiego i Rady 2014/24/ /UE z dnia 26 lutego 2014 r. w sprawie zamówień publicznych, uchylającej dyrektywę 2004/18/WE ${ }^{1}$ (dalej: dyrektywa klasyczna), wprowadzono do europejskiego systemu prawnego dotyczącego zamówień publicznych instytucję jednolitego europejskiego dokumentu zamówienia (dalej: j.e.d.z.). Zgodnie $z$ treścią art. 59 tej dyrektywy jednolitym europejskim dokumentem zamówienia nazywane jest zaktualizowane oświadczenie własne wykonawcy, który

${ }^{1}$ Dz. Urz. UE L 94 z 28.3.2014, str. 65. 
traktowany jest jako dowód wstępny zastępujący zaświadczenia wydawane przez organy publiczne lub osoby trzecie na potwierdzenie, że dany wykonawca spełnia którykolwiek z trzech warunków: nie znajduje się w sytuacji, skutkującej jego wykluczeniem na podstawie art. 57 dyrektywy, spełnia kryteria kwalifikacji określone w art. 58 dyrektywy lub w stosownych przypadkach spełnia obiektywne zasady i kryteria ustalone zgodnie $z$ art. 65 dyrektywy. W wypadku polegania na zdolności innych podmiotów do udziału w postępowaniu j.e.d.z. zawiera również odpowiednie informacje dotyczące tychże podmiotów.

Treść j.e.d.z. obejmuje formalne oświadczenie wykonawcy, stwierdzające, że odpowiednia podstawa wykluczenia nie ma zastosowania lub że odpowiednie kryterium kwalifikacji jest spełnione, a także zawiera istotne informacje wymagane przez instytucję zamawiającą. Ponadto jednolity europejski dokument zamówienia określa organ publiczny lub osobę trzecią odpowiedzialne za wystawienie dokumentów potwierdzających i zawiera formalne oświadczenie, z którego wynika, że wykonawca będzie w stanie na żądanie i bez zwłoki przedstawić te dokumenty potwierdzające.

Jeżeli instytucja zamawiająca może uzyskać odpowiednie dokumenty potwierdzające okoliczności wskazane w oświadczeniu wykonawcy bezpośrednio za pomocą bezpłatnej krajowej bazy danych w dowolnym państwie członkowskim (np. krajowy rejestr zamówień, wirtualna kartoteka przedsiębiorstw, elektroniczny system przechowywania dokumentów lub system kwalifikacji wstępnej), j.e.d.z. zawiera także wymagane informacje. Należą do nich adres internetowy bazy danych, wszelkie dane identyfikacyjne oraz w stosownych przypadkach, niezbędne oświadczenie o wyrażeniu zgody przez wykonawcę.

Wypełniony formularz j.e.d.z. może zostać ponownie wykorzystany przez wykonawcę w postępowaniu o udzielenie zamówienia, pod warunkiem że wykonawca potwierdzi, iż informacje w nim zawarte są nadal prawidłowe. Takie rozwiązanie stanowi znaczne ułatwienie dla wykonawcy, który bierze udział w licznych postępowaniach odbywających się w podobnym okresie.

Jednolity europejski dokument zamówienia jest sporządzany na podstawie standardowego formularza. Dyrektywa przyznała kompe- 
tencję Komisji Europejskiej do określenia standardowego formularza w aktach wykonawczych, a jego przyjęcie zostało przeprowadzone w procedurze sprawdzającej.

W art. 59 ust. 2 dyrektywy klasycznej przewidziano przedstawienie j.e.d.z. w toku postępowania o udzielenie zamówienia publicznego wyłącznie w formie elektronicznej. Wprowadzenie w życie tego przepisu może jednak zostać odroczone przez państwo członkowskie na okres 54 miesięcy od wejścia w życie dyrektywy.

Komisja Europejska została zobowiązana do przeglądu praktycznego stosowania jednolitego europejskiego dokumentu zamówienia, z uwzględnieniem technicznego rozwoju baz danych w państwach członkowskich, i przedstawienia stosownego sprawozdania Parlamentowi Europejskiemu i Radzie przed upływem trzech lat od dnia wejścia w życie dyrektywy klasycznej. Ponadto w stosownych przypadkach Komisja została zobowiązana do przedstawienia wniosków dotyczących transgranicznego dostępu do baz danych i stosowania zaświadczeń i poświadczeń na rynku wewnętrznym² ${ }^{2}$.

Instytucja zamawiająca uprawniona jest do zwrócenia się do oferentów i kandydatów o przedłożenie wszystkich lub niezbędnych dokumentów potwierdzających dane zawarte w formularzu, jeżeli jest to niezbędne do zapewnienia odpowiedniego przebiegu postępowania. Dyrektywa przewiduje również obowiązek zwrócenia się przez instytucję zamawiającą o przedstawienie tych dokumentów do oferenta, któremu ma zostać udzielone zamówienie publiczne (przed jego udzieleniem). Oferenci i kandydaci nie są zobowiązani do przedkładania dokumentów, które można uzyskać $z$ bezpłatnych krajowych baz danych ${ }^{3}$. Wykaz tych baz danych jest udostępniany i aktualizowany przez państwa członkowskie w systemie eCertis ${ }^{4}$.

W dyrektywie Parlamentu Europejskiego i Rady 2014/25/UE z dnia 26 lutego 2014 r. w sprawie udzielania zamówień przez podmioty działające w sektorach gospodarki wodnej, energetyki, transportu i usług pocztowych, uchylającej dyrektywę 2004/17/

2 Art. 59 ust. 3 dyrektywy klasycznej.

${ }^{3}$ Art. 59 ust. 4 i 5 dyrektywy klasycznej.

${ }^{4}$ System dostępny pod adresem internetowym: https://ec.europa.eu/ growth/tools-databases/ecertis/ (dostęp: 4.06.2017 r.). 
/WE (dalej: dyrektywa sektorowa) ${ }^{5}$ zostało zawarte odesłanie do przepisów dyrektywy klasycznej dotyczących jednolitego europejskiego dokumentu zamówienia ${ }^{6}$.

\section{Rozporządzenie ustanawiające standardowy formularz jednolitego europejskiego dokumentu zamówienia}

Komisja Europejska na podstawie upoważnienia zawartego w dyrektywie klasycznej oraz traktatu o funkcjonowaniu Unii Europejskiej (dalej: t.f.UE) ${ }^{7}$ wydała rozporządzenie wykonawcze $2016 / 7$ z dnia 5 stycznia ustanawiające standardowy formularz jednolitego europejskiego dokumentu zamówienia ${ }^{8}$. Oznacza to, że o formie i treści oświadczeń zawartych w j.e.d.z. decyduje dyrektywa, ale sam wzór formularza oraz układ rubryk został przygotowany przez Komisję Europejską i wprowadzony do porządku prawnego za pomocą rozporządzenia. Akt ten zgodnie $z$ zasadami wprowadzonymi przez traktat z Lizbony, zaliczany jest do aktów wykonawczych stanowionych przez Komisję Europejską, wydawanych na mocy art. 291 ust. 2 t.f.UE. Przepis ten przewiduje, że jeżeli konieczne są jednolite warunki wykonywania prawnie wiążących aktów Unii, akty te powierzają uprawnienia wykonawcze Komisji lub w należycie uzasadnionych przypadkach oraz w przypadkach określonych w artykułach 24 i 26 traktatu o Unii Europejskiej, Radzie. W przypadku wydawania aktów tego typu w ich nagłówku musi znajdować się przymiotnik „wykonawcze” lub „wykonawcza”. Oznacza to, że kwestia ta nie została pozostawiona państwom członkowskim do implementacji do krajowych systemów prawnych w celu harmonizacji, tak jak inne

\footnotetext{
${ }^{5}$ Dz. Urz. UE L 94 z 28.3.2014, str. 243.

${ }^{6}$ Art. 80 ust. 3 dyrektywy sektorowej.

7 Dz. Urz. UE C 326/49 z 26 października 2012 r.

${ }^{8}$ Dz. Urz. UE L 3/16 z 6 stycznia 2016 r.

9 J. Barcik, A. Wentkowska, Prawo Unii Europejskiej z uwzględnieniem traktatu z Lizbony, Warszawa 2008, s. 160.
} 
instytucje prawa zamówień publicznych, $z$ reguły wprowadzane przez dyrektywy. W celu realizacji celów wprowadzenia jednolitego europejskiego dokumentu zamówienia przewidziano wydanie źródła prawa wtórnego będące instrumentem ujednolicenia prawa o zasięgu ogólnym, wiążącym w całości i bezpośrednio stosowanym we wszystkich państwach członkowskich ${ }^{10}$.

Taki wybór prawodawcy unijnego oznacza, że konieczna była unifikacja prawa w zakresie wprowadzenia standardowego formularza j.e.d.z., co jednocześnie wykluczyło możliwość przyjmowania czy też utrzymywania w mocy aktów prawa krajowego regulujących te same kwestie czy powielających treść rozporządzenia ${ }^{11}$. Jest to wybór uzasadniony - sama nazwa ,jednolity europejski dokument zamówienia" determinuje konieczność ujednolicenia regulacji dotyczących tej instytucji prawa unijnego, a przy tym tylko w ten sposób mógł zostać zrealizowany postulat uproszczenia procedur zamówieniowych na etapie przystąpienia wykonawcy do postępowania oraz $\mathrm{w}$ konsekwencji wzrostu efektywności postępowania o udzielenie zamówienia publicznego.

Rozporządzenie oprócz samego wzoru formularza j.e.d.z. zawiera również przepis dotyczący wejścia $\mathrm{w}$ życie rozporządzenia (od dnia wejścia w życie krajowych środków wdrażających dyrektywę klasyczną, a najpóźniej 18 kwietnia 2016 r.) oraz instrukcje stosowania formularza (załącznik 1). Wskazano w nich, że j.e.d.z. jest składanym przez wykonawców oświadczeniem własnym stanowiącym dowód wstępny, zastępującym zaświadczenia wydawane przez organy publiczne lub osoby trzecie, powtarzając $\mathrm{w}$ tym zakresie regulację $z$ dyrektywy. Wskazano główny cel wprowadzenia tego dokumentu - zmniejszenie obciążeń administracyjnych wynikających z wymogu przedstawienia znacznej liczby zaświadczeń lub innych dokumentów związanych z kryteriami wykluczenia i kwalifikacji.

${ }^{10}$ Zarys prawa swobód rynku wewnętrznego Unii Europejskiej, red. M.K. Kolasiński, Toruń 2013, s. 27.

${ }^{11}$ P. Justyńska, P. Nowicki, Konsekwencje przyjęcia tzw. nowych dyrektyw zamówieniowych dla krajowego porzadku prawnego, w: Państwo a gospodarka. Instrumenty prawne realizacji zamówień publicznych, red. H. Nowicki, P. Nowicki, Toruń 2015, s. 56-57. 
Umożliwiono również państwom członkowskim wydawanie wytycznych dotyczących stosowania tego dokumentu jako ułatwienia dla wykonawców. W rozporządzeniu przewidziano też obowiązek stosowania j.e.d.z. w stosunku do ofert w procedurze otwartej i wniosków o dopuszczenie do udziału w procedurze ograniczonej, procedurze konkurencyjnej $z$ negocjacjami, dialogu konkurencyjnym lub partnerstwie innowacyjnym.

Zgodnie $z$ treścią instrukcji państwom członkowskim pozostawiono decyzję, czy uregulować lub pozostawić do decyzji instytucji zamawiających i podmiotów zamawiających kwestię, czy należy stosować jednolity europejski dokument zamówienia również w ramach postępowań o udzielenie zamówienia niepodlegających lub niepodlegających w pełni, szczegółowym przepisom proceduralnym dyrektyw zamówieniowych, np. w odniesieniu do udzielania zamówień o wartości poniżej odnośnych progów lub udzielania zamówień podlegających szczególnym przepisom mającym zastosowanie do usług społecznych i innych szczególnych usług.

W dalszej części instrukcji wskazano podział jednolitego europejskiego dokumentu zamówienia na części i sekcje. Część I zawiera informacje dotyczące postępowania o udzielenie zamówienia oraz instytucji zamawiającej lub podmiotu zamawiającego (zakłada się, że system teleinformatyczny służący do obsługi j.e.d.z. będzie posiadał funkcję automatycznego wypełniania tej części $z$ wykorzystaniem informacji udostępnionych przez instytucję zamawiającą, np. ogłoszenia). W części II znajdują się informacje dotyczące wykonawcy, takie jak nazwa, numer ewidencyjny, wielkość przedsiębiorstwa, dane osoby reprezentującej przedsiębiorcę. Część III obejmuje kryteria wykluczenia, tj. informacje o wyrokach za przestępstwa, podstawach wykluczenia ze względu na niewypłacalność, konflikt interesów, wykroczenia zawodowe lub zaległości podatkowe lub w ubezpieczeniach społecznych oraz o innych podstawach wykluczenia przewidzianych przez przepisy krajowe. W części IV zamieszcza się kryteria kwalifikacji (m.in. informacje dotyczące kompetencji, sytuacji finansowej, zdolności technicznej i zawodowej). W części V zawiera się informacje dotyczące spełniania obiektywnych i niedyskryminacyjnych kryteriów lub zasad, które mają być stosowane w celu ograniczenia liczby kandydatów. Część VI obejmuje oświad- 
czenia końcowe wykonawcy, odnoszące się do potwierdzenia, że przedstawione informacje są dokładne i prawidłowe, oraz informacje o konsekwencji poważnego wprowadzenia w błąd.

Od dnia 18 kwietnia 2018 r. j.e.d.z. ma być przedstawiany wyłącznie w formie elektronicznej. Do tego czasu dopuszczalne jest stosowanie tego dokumentu zarówno w formie elektronicznej, jak i „papierowej” - pisemnej ${ }^{12}$.

\section{Jednolity dokument zamówienia}

w prawie krajowym

Pomimo że formularz j.e.d.z. został wprowadzony za pomocą bezpośrednio stosowanego w prawie polskim rozporządzenia, w polskiej Ustawie $z$ dnia 29 stycznia 2004 r. - Prawo zamówień publicznych (dalej: p.z.p.) ${ }^{13}$ znajdują się nieliczne regulacje odnoszące się do tej instytucji, nazywające ją także ,jednolitym dokumentem”.

$\mathrm{W}$ art. 10a przewiduje się, że składanie m.in. oświadczenia, w tym oświadczenie składane na formularzu jednolitego europejskiego dokumentu zamówienia, sporządzonym zgodnie $z$ wzorem standardowego formularza określonego w rozporządzeniu wykonawczym Komisji Europejskiej wydanym na podstawie art. 59 ust. 2 dyrektywy 2014/24/UE oraz art. 80 ust. 3 dyrektywy 2014/25/ /UE, odbywa się przy użyciu środków komunikacji elektronicznej. W ust. 5 tego artykułu wskazuje się, że jednolity dokument sporządza się, pod rygorem nieważności w postaci elektronicznej i opatruje się kwalifikowanym podpisem elektronicznym. Obowiązywanie tych przepisów na mocy art. 15 ust. 2 Ustawy z dnia 22 czerwca 2016 r. o zmianie ustawy - Prawo zamówień publicznych oraz niektórych innych ustaw ${ }^{14} \mathrm{w}$ zakresie jednolitego dokumentu zamówienia zostało odroczone do 18 kwietnia 2018 r.

${ }^{12}$ B. Nuzzo, Jednolity europejski dokument zamówienia, „Prawo Zamówień Publicznych” 2016, nr 1, dostęp el. SIP Legalis.

${ }^{13}$ Tekst jednolity: Dz.U. z 2015 r., poz. 2164 z późn. zm.

14 Dz.U. z 2016 r. poz. 1020. 
W art. 25a ust. 2 p.z.p. wskazuje się, że jeżeli wartość zamówienia jest równa lub przekracza kwoty określone w przepisach wydanych na podstawie art. 11 ust. 8 (tj. kwoty wartości zamówień oraz konkursów, od których jest uzależniony obowiązek przekazywania ogłoszeń Urzędowi Publikacji Unii Europejskiej), oświadczenie w zakresie wskazanym przez zamawiającego w ogłoszeniu o zamówieniu lub w specyfikacji istotnych warunków zamówienia wykonawca składa w formie jednolitego dokumentu. Ponadto w ust. 3 tego przepisu zamieszczono regulację dotyczącą składania jednolitych dokumentów dotyczących podmiotów, na których zasoby powołuje się wykonawca (dotyczy to postępowań przekraczających progi $z$ art. 11 ust. 8 p.z.p.).

Zgodnie $z$ art. 25a ust. 5 p.z.p. wykonawca, który zamierza powierzyć wykonanie części zamówienia podwykonawcom, na żądanie zamawiającego składa jednolite dokumenty dotyczące podwykonawców w celu wykazania braku istnienia wobec nich podstaw wykluczenia $\mathrm{z}$ udziału $\mathrm{w}$ postępowaniach dotyczących zamówień przekraczających wartość wskazaną w art. 11 ust. 8 p.z.p.

W przypadku wspólnego ubiegania się o zamówienie przez wykonawców każdy $z$ nich obowiązany jest złożyć oświadczenie lub jednolity dokument. Powtarzając uregulowania dyrektywy, polski ustawodawca wskazał, że wykonawca może wykorzystać w jednolitym dokumencie nadal aktualne informacje, zawarte $\mathrm{w}$ innym jednolitym dokumencie, złożonym w odrębnym postępowaniu o udzielenie zamówienia ${ }^{15}$.

Ostatni przepis w ustawie polskiego prawa krajowego dotyczącego zamówień publicznych wyłącza stosowanie przepisów ustawy dotyczących jednolitego europejskiego dokumentu zamówienia w postępowaniach o udzielenie zamówienia w dziedzinach obronności i bezpieczeństwa ${ }^{16}$.

Podsumowując, polskie przepisy prawa krajowego dotyczące j.e.d.z. w zasadniczej części powtarzają przepisy prawa unijnego (dyrektyw oraz rozporządzenia). Polski ustawodawca zatem nie skorzystał z możliwości przewidzianej w rozporządzeniu dotyczącej

\footnotetext{
${ }^{15}$ Art. 25a ust. 6 i 7 p.z.p.

${ }^{16}$ Art. 131e ust. 2a pkt 1 p.z.p.
} 
stosowania j.e.d.z. w ramach postępowań o udzielenie zamówienia niepodlegających w ogóle lub w pełni szczegółowym przepisom proceduralnym dyrektyw zamówieniowych.

\section{Cele wprowadzenia jednolitego europejskiego dokumentu zamówienia}

Jak wskazano, w rozporządzeniu wykonawczym jako główny cel wprowadzanych regulacji Komisja Europejska wskazała zmniejszenie obciążeń administracyjnych wynikających z wymogu przedstawienia znacznej liczby zaświadczeń lub innych dokumentów związanych z kryteriami wykluczenia i kwalifikacji.

Zdaniem Pedra Tellesa można wyróżnić trzy główne cele wprowadzenia jednolitego europejskiego dokumentu zamówienia. Pierwszym $z$ nich jest redukcja nakładu pracy podejmowanego przez wykonawców na początku procedury zamówieniowej, drugim wskazanie instytucjom, gdzie znajdują się dokumenty potwierdzające dane zawarte w oświadczeniu, trzecim - udostępnienie instytucjom zamawiającym baz danych, w których zawarte zostały niezbędne informacje dotyczące wykonawców ${ }^{17}$.

Należy zauważyć, że cele wprowadzenia j.e.d.z. należy rozważać również w szerszym kontekście - jako elementu elektronizacji całego systemu zamówień publicznych. Docelowo - od 2018 r. - dokument ten będzie mógł być składany wyłącznie w formie elektronicznej. Przygotowanie w tym celu nowego formularza, wprowadzonego rozporządzeniem wykonawczym, a zatem jednolitego dla wszystkich państw członkowskich, należy oceniać pozytywnie. Podstawowym błędem informatyzacji niektórych skomplikowanych procedur rozbudowanych w systemie papierowym jest zastępowanie ich systemem informatycznym poprzez jego „nałożenie” na istniejące procedury, bez przeprowadzenia analizy w zakresie kolizji i dublowania czyn-

17 P. Telles, The European Single Procurement Document, "Procurement Law Journal" 2017, nr 1, https://papers.ssrn.com/Sol3/Delivery.cfm/SSRN_ ID2969066_code2103912.pdf?abstractid=2969066\&mirid=1 (dostęp: 5.06. 2017 r.). 
ności ${ }^{18}$. W przypadku j.e.d.z. stworzono zupełnie nowy formularz, który stanowi oświadczenie własne wykonawcy, stosowane zamiast dostarczenia od razu przez wszystkich uczestników postępowania już na początku procedury wszystkich zaświadczeń i dokumentów. Dzięki temu możliwe było dostosowanie tego formularza do potrzeb systemu informatycznego, który będzie pozwalał na bieżące aktualizowanie informacji dotyczących wykonawcy. Ponadto ważna jest możliwość umieszczenia odnośników do wymaganych dokumentów, których uzyskanie możliwe jest za pośrednictwem teleinformatycznych baz danych, co znacząco poprawi obieg tymi dokumentami i usprawni procedurę zamówieniową. Należy oczekiwać, że z czasem coraz więcej dokumentów oraz certyfikatów uzyskiwanych przez wykonawców będzie możliwe do weryfikacji za pomocą systemów teleinformatycznych (na tej samej zasadzie, jak w Polsce działają już rejestry KRS oraz CEIDG).

Istotna jest również z punktu widzenia wykonawców cecha interoperacyjności, a co za tym idzie: zmniejszenie możliwości stosowania zakazanej dyskryminacji ze względu na pochodzenie oraz zwiększenie konkurencji na rynku zamówień publicznych. System elektroniczny, na którym oparty jest j.e.d.z., umożliwia stosowanie jednolitego formularza niezależnie od używanego języka (system umożliwia wyświetlanie formularza w dowolnym języku) ${ }^{19}$, co wraz z wykorzystaniem systemu eCertis znacznie usprawnia możliwość udziału wykonawców z innych państw członkowskich, które do tej pory nie mogły brać udziału w związku z kosztami uzyskania odpowiednich dokumentów, tłumaczeń oraz kosztów dostarczenia korespondencji.

Ponadto wstępna kontrola j.e.d.z. umożliwia znaczne przyspieszenie procedur w stosunku do wykonawców, co do których już Z samej treści tego oświadczenia wynika konieczność odrzucenia ich ofert, np. $z$ uwagi na zakaz prowadzenia działalności gospodarczej w wymaganym zakresie. Konieczność uzyskania całości dokumentacji dotyczącej zamówienia dopiero od podmiotu, który

18 E. Gnatowska, Z. Perčić, W. Jarzyński, Komentarz do ustawy Prawo zamówień publicznych, Warszawa 2016, s. 99-100.

19 https://ec.europa.eu/tools/espd (dostęp: 4.06.2017 r.). 
został wyłoniony w procedurze zamówieniowej, znacznie przyspiesza procedurę i ogranicza zasoby instytucji zamawiających konieczne do weryfikacji dokumentacji, a możliwość każdorazowego żądania potwierdzenia informacji zawartych $\mathrm{w}$ j.e.d.z. odpowiednimi dokumentami w każdym czasie zabezpiecza instytucję zamawiającą w przypadku wątpliwości co do treści oświadczenia.

Można więc uznać, że jednolity europejski dokument zamówienia może być traktowany przez zamawiającego jako dowód prima facie $^{20}$ potwierdzający spełnianie przez wykonawcę podstawowych przesłanek udziału w postępowaniu i braku podstaw do wykluczenia wykonawcy.

\section{Charakter prawny jednolitego europejskiego dokumentu zamówienia}

Jednolity europejski dokument zamówienia stanowi, jak już wskazano, formalne oświadczenie własne wykonawcy stwierdzające, że odpowiednia podstawa wykluczenia nie ma zastosowania lub że odpowiednie kryterium kwalifikacji jest spełnione, a także zawiera istotne informacje wymagane przez instytucję zamawiającą. Oznacza to, że należy postrzegać j.e.d.z. jako oświadczenie wiedzy.

Oświadczenie wiedzy polega na przekazaniu przez określony podmiot informacji, będących uzewnętrznieniem treści intelektualnych przez niego posiadanych, innemu podmiotowi lub podmiotom. Choć ze złożeniem oświadczenia wiedzy ustawodawca może łączyć określone skutki prawne, celem osoby składającej takie oświadczenie nie jest bezpośrednio dokonanie czynności prawnej ${ }^{21}$.

Do oświadczeń wiedzy stosuje się przepisy prawa cywilnego. Zgodnie $z$ art. 651 Ustawy $z$ dnia 23 kwietnia 1964 r. - Kodeks cywilny $^{22}$, przepisy o oświadczeniach woli stosuje się odpowiednio do

20 Tak P. Telles, op. cit.

${ }^{21}$ Wyrok SN z dnia 16 lutego 2017 r., sygn. I CSK 106/16, http://www. sn.pl/sites/orzecznictwo/Orzeczenia3/I\%20CSK\%20106-16-1.pdf (dostęp: 6.06.2017 r.).

${ }^{22}$ T. jedn.: Dz.U. z 2017 r. poz. 459 z późn. zm. 
innych oświadczeń, a więc także do oświadczeń wiedzy. W doktrynie wskazuje się, że do tego typu oświadczeń można stosować odpowiednio przepisy dotyczące m.in. błędu, komunikowania, wykładni ${ }^{23}$.

Poważne konsekwencje może rodzić podanie przez wykonawcę w j.e.d.z. informacji nieprawdziwych, stanowiące poważne wprowadzenie w błąd zamawiającego. Po pierwsze, będzie ono skutkować wykluczeniem takiego wykonawcy z postępowania. Może to wynikać $z$ treści specyfikacji istotnych warunków zamówienia, niezależnie od tego podstawą wykluczenia jest art. 24 ust. 1 p.z.p. W punkcie 12 ustawodawca określił przesłankę wykluczenia wykonawcy, który spełnił warunków udziału w postępowaniu lub nie został zaproszony do negocjacji lub złożenia ofert wstępnych albo ofert, lub nie wykazał braku podstaw wykluczenia (informacje te są integralną częścią j.e.d.z.). W punkcie 16 tego ustępu wskazano kolejną przesłankę wykluczenie wykonawcy, który w wyniku zamierzonego działania lub rażącego niedbalstwa wprowadził zamawiającego w błąd przy przedstawieniu informacji, że nie podlega wykluczeniu, spełnia warunki udziału w postępowaniu lub obiektywne i niedyskryminacyjne kryteria, lub który zataił te informacje lub nie jest w stanie przedstawić wymaganych dokumentów, natomiast w punkcie 17 uregulowano wykluczenie wykonawcy, który w wyniku lekkomyślności lub niedbalstwa przedstawił informacje wprowadzające w błąd zamawiającego, mogące mieć istotny wpływ na decyzje podejmowane przez zamawiającego $\mathrm{w}$ postępowaniu o udzielenie zamówienia. Przepisy te w zasadniczej części przypadków są wystarczające do wykluczenia wykonawcy, który wskazał nieprawdziwe dane w j.e.d.z.

Wykonawca, który składa nieprawdziwe oświadczenie w formularzu j.e.d.z., musi także liczyć się z odpowiedzialnością karną. W zależności od kwalifikacji prawnej czynu mogą tu znaleźć zastosowanie m.in. artykuły $233 \S 1$ (dotyczący fałszywych zeznań), $297 \S 1$ (dotyczący przedkładania podrobionego, przerobionego, poświadczającego nieprawdę albo nierzetelnego dokumentu, albo nierzetelnego, pisemnego oświadczenia dotyczącego okoliczności o istotnym znaczeniu dla uzyskania wymienionego wsparcia fi-

${ }^{23}$ Kodeks cywilny, t. 1: Komentarz art. 1-44911, red. M Gutowski, Warszawa 2016, s. $447-448$. 
nansowego, instrumentu płatniczego lub zamówienia publicznego) oraz 305 § 2 (dotyczący rozpowszechniania w związku z publicznym przetargiem lub przemilczania istotnych okoliczności mających znaczenie dla zawarcia umowy będącej przedmiotem przetargu albo wchodzenia $w$ porozumienie $z$ inną osobą, działając na szkodę właściciela mienia albo osoby lub instytucji, na rzecz której przetarg jest dokonywany) Ustawy z dnia 6 czerwca 1997 r. - Kodeks karny ${ }^{24}$.

\section{Podsumowanie}

Wprowadzenie do europejskiego (a w konsekwencji także do polskiego systemu prawnego) jednolitego europejskiego dokumentu zamówienia ma różnorakie skutki prawne. Oświadczenie to można uznać za rozwiązanie rewolucyjne $z$ kilku powodów.

Po pierwsze, formularz j.e.d.z. został wprowadzony rozporządzeniem wykonawczym Komisji Europejskiej, co nie było dotąd instrumentem szeroko stosowanym w sektorze zamówień publicznych (jednym $z$ wyjątków były rozporządzenia Komisji uaktualniające progi stosowania dyrektyw unijnych, np. rozporządzenie Komisji UE 2015/2340 z dnia 15 grudnia 2015 r. zmieniające dyrektywę Parlamentu Europejskiego i Rady 2009/81/WE w odniesieniu do progów obowiązujących w zakresie procedur udzielania zamówień) ${ }^{25}$. Nawet przepisy dotyczące elektronizacji zamówień publicznych i wprowadzania systemów teleinformatycznych do tej pory były przeprowadzane w ramach harmonizacji, a nie ujednolicania prawa państw członkowskich. Zastosowanie tego rozwiązania praktycznie wyklucza możliwość wystąpienia problemów dotyczących naruszenia zasady niedyskryminacji wykonawców już na początkowym etapie postępowania. Należy pamiętać, że poprzez system zamówień publicznych Unia Europejska realizuje zasadę niedyskryminacji w polityce unijnej ${ }^{26}$, w związku z czym rozwiązanie ułatwiające

${ }^{24}$ T. jedn. Dz U. z 2016 r. poz. 1137 z późn. zm.

25 Dz. Urz. UE L 330/14 z 16 grudnia 2015 r.

${ }^{26}$ M. Królikowska-Olczak Zasada niedyskryminacji $w$ prawie zamówień publicznych Unii Europejskiej, w: Ekonomiczne i prawne zagadnienia zamó- 
równy dostęp do zamówień publicznych we wszystkich państwach członkowskich zasługuje na pełną aprobatę.

Po drugie, jednolity europejski dokument zamówienia stanowi nowe oświadczenie wiedzy wykonawcy, które zastępuje liczne zaświadczenia, oświadczenia i dokumenty, wymagane do tej pory od wykonawców, stając się dowodem prima facie potwierdzającym spełnianie przez wykonawcę wymagań wskazanych przez instytucję zamawiającą koniecznych do udziału w postępowaniu, dzięki czemu możliwe jest znaczne przyspieszenie i uproszczenie wstępnego etapu procedury zamówieniowej.

Należy jednak zauważyć, że $z$ treścią j.e.d.z. nie wiążą się żadne szczególne domniemania prawne, a wszelkie informacje w nim zawarte mogą być weryfikowane za pomocą zobowiązania do dostarczenia odpowiednich dokumentów przez instytucję zamawiającą. W stosunku do wykonawcy, który został wyłoniony w procedurze zamówieniowej wprowadzono obowiązek potwierdzenia składanych oświadczeń stosowną dokumentacją wymaganą przez zamawiającego. Do czasu upowszechnienia prowadzenia baz danych dotyczących odpowiedniej dokumentacji w systemie teleinformatycznym, mogą się zatem zdarzać przypadki, w których wykonawca nie będzie w stanie przedstawić na końcowym etapie właściwych dokumentów. Może przez to zaistnieć ryzyko znacznego wydłużenia procedury na końcowym etapie - bezpośrednio przed zawarciem umowy o zamówienie publiczne.

Istotne są również zagrożenia dotyczące wprowadzenia jednolitego formularza dla wszystkich państw członkowskich, w których jednak istnieją zróżnicowane przepisy dotyczące rejestracji przedsiębiorców, ich form organizacyjno-prawnych, posiadania zezwoleń i koncesji itp. Formularz siłą rzeczy zawiera tylko najważniejsze informacje, używając siatki pojęć możliwej do zastosowania dla wszystkich wykonawców, ale samo zastosowanie formularza może nie być wystarczające do weryfikacji statusu prawnego wykonawcy. Dlatego istotne będzie dalsze rozwijanie i harmonizacja systemów

wień publicznych. Polska na tle Unii Europejskiej. Międzynarodowa konferencja naukowa 21-22 czerwca 2010 r., w Łodzi, red. A. Borowicz, M. Królikowska-Olczak, J. Sadowy, W. Starzyńska, Warszawa 2010. 
teleinformatycznych umożliwiających zweryfikowanie niezbędnych dokumentów.

W konsekwencji należy uznać, że aby jednolity europejski formularz zamówienia spełniał właściwie swoje zadanie, konieczna jest gruntowna i jak najszybsza elektronizacja całego systemu zamówień publicznych Unii Europejskiej, zarówno pod względem prawnym (przygotowania odpowiednich procedur elektronicznych, usprawnienia możliwości składania dokumentów i komunikacji z wykorzystaniem profilu zaufanego), jak i technicznym (przede wszystkim pod kątem interoperacyjności).

\section{STRESZCZENIE}

Jednolity europejski dokument zamówienia aspekty prawne

Jednolity europejski dokument zamówienia jest oświadczeniem własnym dotyczącym kondycji finansowej oraz zdolności do udziału wykonawcy $\mathrm{w}$ postępowaniu o udzielenie zamówienia publicznego. Stanowi on dowód prima facie potwierdzający wypełnianie kryteriów udziału w postępowaniu zamówieniowym na terenie całej Unii Europejskiej. Zgodnie $z$ nowymi dyrektywami zamówieniowymi j.e.d.z. będzie prowadzony wyłącznie w formie elektronicznej, jednak do 18 kwietnia 2018 roku za równoprawne uważa się formy elektroniczną i papierową. Jego celem jest doprowadzenie do sytuacji, w której przedsiębiorcy mogą udowodnić spełnianie kryteriów oraz niepodleganie wykluczeniu bez potrzeby przedstawiania pełnej dokumentacji na początkowym etapie postępowania.

Słowa kluczowe: zamówienia publiczne; jednolity europejski dokument zamówienia; j.e.d.z.

\section{SUMMARY}

The legal aspects of the European Single Procurement Document

The European Single Procurement Document is a self-declaration of a business's financial status, abilities, and suitability for public procurement 
procedures. It is used as prima facie evidence of the fulfilment of the conditions required in public procurement procedures across the European Union. According to the new public procurement directives, the ESPD shall be provided exclusively in electronic form. However, both electronic and paper versions of the ESPD may exist until 18 April 2018. It has led to a situation in which companies can prove that they fulfil the exclusion and selection criteria of a tender without a requirement to submit various documents at the beginning of a tender.

Keywords: public procurement; European Single Procurement Document; ESPD

\section{BIBLIOGRAFIA}

Barcik J., Wentkowska A., Prawo Unii Europejskiej z uwzględnieniem traktatu z Lizbony, Warszawa 2008.

Gnatowska E., Perčić Z., Jarzyński W., Komentarz do ustawy Prawo zamówień publicznych, Warszawa 2016.

Justyńska P., Nowicki P., Konsekwencje przyjęcia tzw. nowych dyrektyw zamówieniowych dla krajowego porzadku prawnego, w: Państwo a gospodarka. Instrumenty prawne realizacji zamówień publicznych, red. Nowicki H., Nowicki P., Toruń 2015.

Kodeks cywilny, t. 1: Komentarz art. 1-44911, red. Gutowski M., Warszawa 2016.

Królikowska-Olczak M., Zasada niedyskryminacji $w$ prawie zamówień publicznych Unii Europejskiej w: Ekonomiczne i prawne zagadnienia zamówień publicznych. Polska na tle Unii Europejskiej. Międzynarodowa konferencja naukowa 21-22 czerwca 2010 r. w Łodzi, red. Borowicz A., Królikowska-Olczak M., Sadowy J., Starzyńska W. Warszawa 2010.

Nuzzo B., Jednolity europejski dokument zamówienia, „Prawo Zamówień Publicznych” 2016, nr 1, dostęp el. SIP Legalis.

Telles P., The European Single Procurement Document, "Procurement Law Journal” 2017, nr 1, https://papers.ssrn.com/Sol3/Delivery.cfm/SSRN_ ID2969066_code2103912.pdf?abstractid=2969066\&mirid=1 (dostęp: 5.06.2017 r.).

Zarys prawa swobód rynku wewnętrznego Unii Europejskiej, red, Kolasiński M.K., Toruń 2013. 